\title{
IMPACT OF ENVIRONMENTAL POLLUTION ON CARBOXYHEMOGLOBIN LEVELS AMONG SMOKING AND NON- SMOKING MOTORCYCLE TAXI DRIVERS
}

\author{
IMPACTO DA POLUIÇÃO AMBIENTAL NO NÍVEL DE CARBOXIHEMOGLOBINA \\ ENTRE MOTOTAXISTAS TABAGISTAS E NÃO TABAGISTAS
}

\begin{abstract}
Luiz Almeida SILVA ${ }^{1}$; Maria Lúcia do Carmo Cruz ROBAZZI ${ }^{2}$; Hildeu Ferreira ASSUNÇÃ ${ }^{3}$; Rita de Cassia de Marchi Barcelos DALRI ${ }^{4}$; Ludmila Grego MAIA ${ }^{5}$; Sebastião Elias da SILVEIRA ${ }^{6}$; Guilherme Silva de MENDONÇA ${ }^{7}$; Marcelo Fouad RABAHI ${ }^{8}$; Celmo Celeno PORTO ${ }^{9}$

1. Health Sciences Academic Unit. Federal University of Goiás, Catalão, Goiás, Brazil. enferluiz@ yahoo.com.br; 2. Fundamental Nursing Department of Ribeirao Preto Nursing School, University of São Paulo, Ribeirão Preto, São Paulo, Brazil; 3. Department of Agricultural Sciences, Federal University of Goiás, Jataí, Goiás, Brazil; 4. Department of Fundamental Nursing, Ribeirao Preto Nursing School, University of São Paulo, Ribeirão Preto, São Paulo, Brazil; 5. Health Sciences Academic Unit. Federal University of Goiás, Jataí, Goiás, Brazil; 6. Fundamental Nursing Department of Ribeirao Preto Nursing School, University of São Paulo, Ribeirão Preto, São Paulo, Brazil; 7. Nurse, Pedagogue, Master and Doctorate in Health Sciences - Post-Graduate Program in Health Sciences, Federal University of Uberlândia, Uberlândia, MG, Brazil; 8. Faculty of Medicine, Federal University of Goiás, Goiânia, Goiás, Brazil; 9. Faculty of Medicine. Federal University of Goiás, Goiânia, Goiás, Brazil.
\end{abstract}

\begin{abstract}
Studies related to environmental pollution, carbon monoxide levels and smoking need to be deepened, especially in the case of traffic workers. Therefore, the objective was to verify the association between environmental carbon monoxide and carboxyhemoglobin levels among smoking and non-smoking motorcycle taxi drivers. A longitudinal epidemiological study was carried out with 95 motorcycle taxi drivers with measurement of the environmental carbon monoxide, carboxyhemoglobin in the exhaled air in three moments with interval of six months, between June 2014 and March 2015, as well as sociodemographic and occupational characteristics of these workers. The seasons of the year presented different carbon monoxide averages $(p<0.05)$, with higher levels in the spring and lower in the autumn, while carboxyhemoglobin levels among smokers and non-smokers were high in the winter, fair in the spring and low in the autumn. Statistical differences were observed between subgroups: between autumn and spring for nonsmokers $(\mathrm{p}=0.024)$ and between winter and autumn for smokers $(\mathrm{p}=0.042)$. There was a positive correlation between carbon monoxide and carboxyhemoglobin levels for non-smokers $\left(\mathrm{r}_{\mathrm{s}}=0.9983 ; \mathrm{p}<0.01\right)$. Environmental pollution represented different levels in the four seasons of the year and significant association with carboxyhemoglobin levels.Thecarboxyhemoglobin levels were higher among smokers, with statistical significance between winter and fall seasons, while non-smokers presented normal levels, whatconfirms the direct influence of tobacco in carboxyhemoglobin levels.
\end{abstract}

KEYWORDS: Environmental pollution. Smoking habit. Occupational Health. Carboxyhemoglobin.

\section{INTRODUCTION}

Health and environment studies began in industrialized countries in the 1960s, when the Rome Club Report was published proposing to slow down the growth of industrial processes and other polluting activities (OLIVEIRA, 2012; SENECHAL et. al., 2015).

The presence of substances in the atmosphere resulting from human activities such as biomass fires and the use of petroleum-based automotive vehicles has been implicated in the genesis of environmental pollution, the latter being the main culprits (DRUMM et. al., 2014).

Personal habits are also factors that contribute to increased exposure to $\mathrm{CO}$, particularly smoking, by inhaling high $\mathrm{CO}$ content at the moment of tobacco combustion. CO has a high affinity with hemoglobin, forming the carboxyhemoglobin complex $(\mathrm{COHb})$ responsible for the transport of oxygen. Elevated levels of $\mathrm{COHb}$ may cause decreased perception and visual acuity, dizziness, headache, nausea, vomiting, acute myocardial infarction, and, at high concentrations, death by asphyxiation (CANÇADO et. al., 2006; SALDIVA, 2010; BLEEKER, 2015; BARROS et. al., 2012; MENDES et. al., 2010; SILVA; ROBAZZI; TERRA, 2013).

In terms of the health of those that work in a traffic related environment, many of whom are exposed to the elements shaped by pollution, agglomeration of vehicles, heat, dust, all of which make it necessary for the researchers to pay special attention, in that they can better understand how these environmental conditions may affect the welfare of workers and the level of risk they face, as 
well as for the passengers that they transport (SILVA; ROBAZZI; TERRA, 2013).

In this perspective, the present study seeks to evaluate the impact of environmental pollution on the level of carboxyhemoglobin among cigarette smoking and non-smoking motorcycle taxi drivers.

\section{MATERIAL AND METHODS}

Quantitative, epidemiological and longitudinal study carried out with motorcycle taxi drivers of the city of Jataí, Goiás, Brazil, located in southwest Goiás, with a population of 93.759 inhabitants. This population-based study included the 152 motorcycle taxi drivers affiliated to the motorcycle taxi drivers union (SIMOTAX) of this city (JATAÍ, 2007).

The motorcycle taxi drivers were approached in their workplaces and data collection was performed at the end of the day. They received
SILVA, L. A. et al.

the necessary information about the study, from the reading of the Informed Consent form, and they were informed that the research would be carried out in three stages: the first one in June, the second in December 2014 and the third in May 2015. In these three collection moments, $\mathrm{COHb}$ levels in the exhaled air would be measured. A sociodemographic questionnaire was filled in the first collection.

The criteria for selecting drivers were: to work for at least six months in this profession, not having detected cardiovascular or respiratory disease or anemia self-reported. Those who, for any reason, did not participate in the second and third stages of the study were excluded.

Ninety-seven out of the 152 motorcycle taxi drivers met the selection criteria and started the study; in the second stage, there were two losses, remaining 95 participants, which represented $62.5 \%$ of the total population(152).

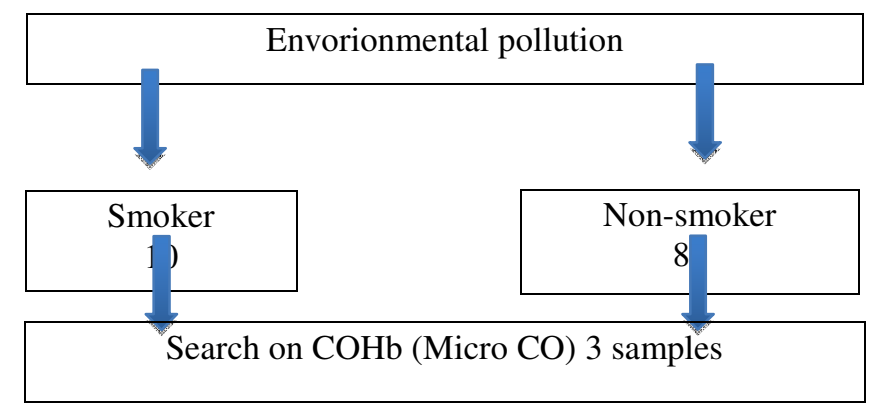

Figure I. Sample and stages of the study

A Micro CO Meter produced by Micro Medical Ltd., Rochester, UK, Gold Standard and previously calibrated was used for $\mathrm{COHb}$ measurements. This device is able to measure the concentration of exhaled carbon monoxide (COex) and $\mathrm{COHb}$ by means of an electrochemical sensor, having the following technical properties: resolution of $1 \mathrm{ppm}$ (parts per million), immediate demonstration of the levels in ppm and percentage of $\mathrm{COHb}$ with carbon monoxide measurement at a concentration of $0-500 \mathrm{ppm}$, operating range 0 to $40^{\circ}$ at atmospheric pressure (TAMUSSINO\&CIA, 2013).

The standard that regulates biological monitoring in Brazil recommends the use of $\mathrm{COHb}$ as a bioindicator of $\mathrm{CO}$ exposure, with a reference value of up to $1 \%$ of blood concentration and the Maximum Allowed Biological Index of 3.5\%, whose values coincide with those proposed by American Conference of Governmental Industrial Hygienists (ACGIH, 1999).
Data collection followed the sequence: in the first stage, motorcycle taxi drivers were approached in their work places at the end of the afternoon and invited to complete the sociodemographic questionnaire. In order to measure $\mathrm{COHb}$, the participants remained in seated position, asked to inhale, pause for 20 seconds and then slowly and completely exhale the air in the mouthpiece of the device (TAMUSSINO; CIA, 2013). In the second collection, in December 2014, only $\mathrm{COHb}$ levels were measured, in the evening, following the previously established parameters. In the third collection, in May of 2015, a new measurement of $\mathrm{COHb}$ was performed. In the case of smokers, having smoked a cigarette within the last 30 minutes was adopted as criterion at all stages.

At the same time, the environment was monitored by measuring $\mathrm{CO}$ in the air in four strategic points of the city with records throughout 12 months, for four hours a day every 30 seconds, two consecutive weeks at the beginning of each 
season; the following measurements were carried out one day per week until the start of the next season. Measurements were coincident with the period of collection of data from motorcycle taxi drivers, using a PorTable Digital CO Meter Minipa MCO-100, with values in ppm.

The distribution of $\mathrm{CO}$ levels and location of motorcycle taxi points are shown in Figure 2.

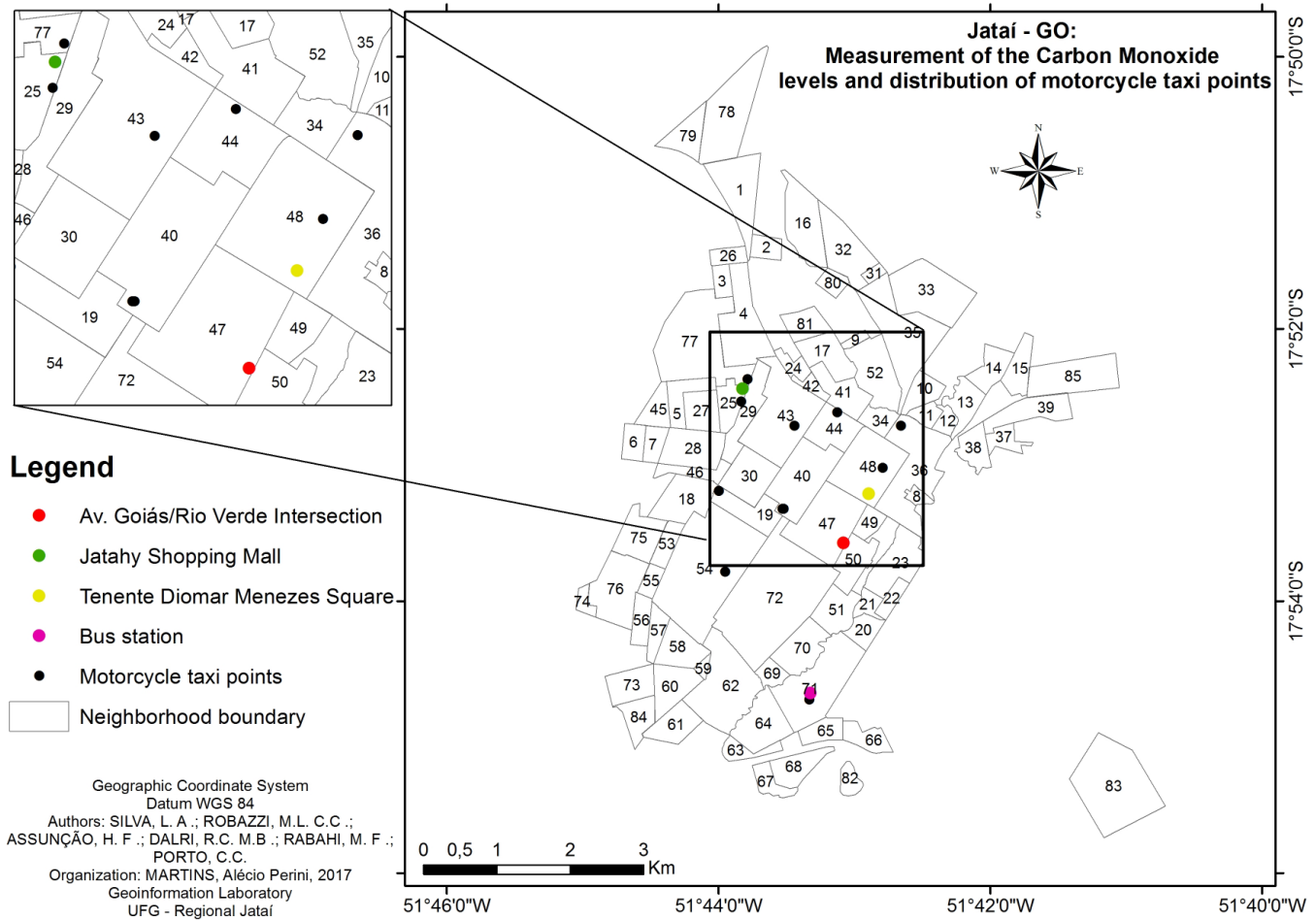

Figure 2. Map of the distribution of monitoring points and motorcycle taxi points. Jataí, Goiás, Brazil, 2015.

Primary and secondary standards set by the National Environmental Council (CONAMA) for $\mathrm{CO}$ emission are: average concentrations of up to 9 ppm of CO every 8 hours and average concentration of 35 ppm every one hour (BRASIL, 1990).

The data obtained was double-entered in an electronic Excellspreadsheet and analyzed in theStatistical Package for Social Sciences (SPSS) for Windows, version 22.0 and STATA, version 12.0. Initially, a descriptive analysis of variables related to baseline characteristics was performed. Quantitative variables were presented as means and standard deviation (SD) and qualitative variables as absolute and relative frequencies.

The Kolmogorov-Smirnov test with Lilliefors correction was used to test normality of quantitative variables.

The following statistical analyses were performed: Spearman correlation between environmental $\mathrm{CO}$ levels in winter, spring, summer and autumn, as well as between $\mathrm{CO}$ and $\mathrm{COHb}$ environmental levels; Friedman test to evaluate differences in $\mathrm{COHb}$ concentration levels during the three periods, which were investigated for each group, separating smokers and non-smokers. In the case of statistical significance, Post hoc tests for multiple comparisons between winter, spring and autumn were used. The Mann-Whitney test was used to assess differences in $\mathrm{COHb}$ concentrations between smokers and non-smokers in each season. The association between environmental $\mathrm{CO}$ and $\mathrm{COHb}$ was tested considering $\mathrm{CO}$ as the predictor variable.

In all tests, $\mathrm{p}$ values $<0.05$ were considered statistically significant.

The study was approved by the Research Ethics Committee of the Federal University of Goiás, under Opinion 609.327.

\section{RESULTS}

Among the 95 motorcycle drivers analyzed, 98.9\% were males, $68.4 \%$ had primary education, $66.7 \%$ were black or brown; $50.5 \%$ had partners, $89.5 \%$ were non-smokers and $67.4 \%$ had already suffered occupational accidents. The mean age and monthly income were $39.09 \pm 8.71$ years and $2439.35 \pm 1,428.34$ Brazilian Reals, respectively (Table 1). 
Table 1. Personal and occupational characteristics of motorcycle taxi drivers. Jataí, Goiás, Brazil, 2015.

\begin{tabular}{lcc}
\hline \multicolumn{1}{c}{ Variables } & Mean or n & SD or \% \\
\hline Age (years) & 39.09 & 8.71 \\
Monthly income (Brazilian Reals) & 2.439 .35 & 1.428 .34 \\
Marital status & & \\
Without partner & 47 & 49.5 \\
With partner & 48 & 50.5 \\
Skin color & & \\
White & 32 & 33.7 \\
Black/brown & 63 & 66.3 \\
Schooling & & \\
Primary education & 65 & 68.4 \\
Secondary education & 30 & 31.6 \\
Smoker & & \\
Yes & 10 & 10.5 \\
No & 85 & 89.5 \\
Number of cigarettes/day * & & 70.0 \\
$\leq 20$ & 7 & 30.0 \\
$>20$ & 3 & 67.4 \\
Occupational Accident & & 32.6 \\
Yes & 64 & \\
No & 31 &
\end{tabular}

The pollution levels obtained by monitoring the environmental $\mathrm{CO}$ during the 12-month period, according to the seasons, are shown in Figure 3. The highest $\mathrm{CO}$ average $(5.1[\mathrm{SD}] \pm 4.24 \mathrm{ppm})$ was observed in the spring, followed by the summer, with similar levels (4.98 [SD] \pm 4.40). Winter presented the lowest rate of environmental $\mathrm{CO}(3.71$ $[\mathrm{SD}] \pm 3.80)$.

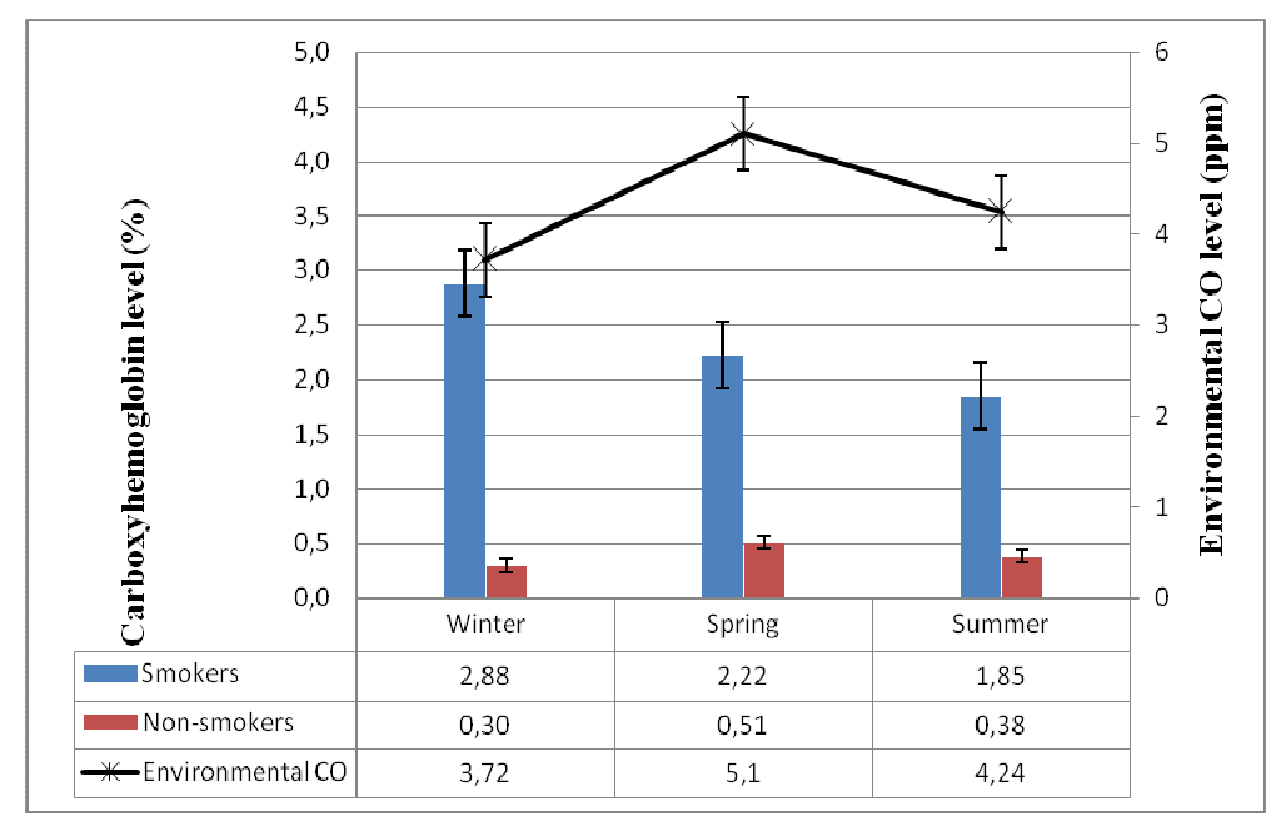

Figure 3. Environmental carbon monoxide concentration and carboxyhemoglobin levels among smokers and non-smokers. Jataí, Goiás, Brazil, 2015.

Concerning $\mathrm{COHb}$ levels among smokers and non-smokers, high levels were observed among smokers in the winter, with intermediate values in the spring and low values in the autumn. In the case of non-smokers, there were no significant differences between seasons, although the spring average was slightly higher. The Friedman test indicated a statistical difference between subgroups, in autumn and spring, for non-smokers $(\mathrm{p}=0.024)$. On the other hand, statistical difference between 
$\mathrm{COHb}$ levels in winter and autumn were seen among smokers $(p=0.042)$. Finally, the comparison of $\mathrm{COHb}$ levels between smokers and non-smokers was statistically different only in the winter $(\mathrm{p}<0.001)$ (Figure 3).

Whereas the environmental $\mathrm{CO}$ showed an increasing tendency in the spring, intermediate values were observed in the winter and summer, with decrease in the autumn. With the objective of evidencing relations between $\mathrm{CO}$ levels in the seasons, the Spearman correlation analysis showed significant relations $(\mathrm{p}<0.001)$ for all pair-wise comparisons, i.e. between winter and summer ($0.020, \mathrm{p}<0.01)$, winter and autumn $(-0.173)$, winter and spring (-0.078), autumn and spring (0.287), autumn and summer (0.136), and spring and summer (0.015) (Table 2).

Table 2. Correlation coefficient between different seasons of the year. Jataí, Goiás, Brazil, 2015.

\begin{tabular}{|c|c|c|c|c|}
\hline Season & Winter & Fall & Primavera & Summer \\
\hline Winter & 1.000 & - & - & - \\
\hline Fall & $-0.173 *$ & 1.000 & - & - \\
\hline Primavera & $-0.078^{*}$ & $0.287^{*}$ & 1.000 & - \\
\hline Summer & $-0.020 * *$ & $0.136^{*}$ & 0.015 & 1.000 \\
\hline
\end{tabular}

Spearman Correlation $\left(\mathrm{r}_{\mathrm{s}}\right) ; * \mathrm{p}<0.001 ; * * \mathrm{p}<0.01$.

Regarding the relationship between environmental $\mathrm{CO}$ levels and $\mathrm{COHb}$ levels in motorcycle taxi drivers, there was a significantly perfect positive correlation among non-smokers $\left(\mathrm{r}_{\mathrm{s}}=\right.$ 0.998; $\mathrm{P}<0.01)$. On the other hand, smokers had a negative but non-significant correlation $(-0.500 ; \mathrm{p}>$ $0.05)$.

In the simple linear regression analysis, using smokers as reference, we observed an association between environmental $\mathrm{CO}$ and $\mathrm{COHb}$ levels among non-smokers ( $\beta$ : $0.988 ; 95 \%$ CI: 0.24; $1.55, \mathrm{p}=0.03$ ), with $\mathrm{R}^{2}=0.996$.

\section{DISCUSSION}

The environmental $\mathrm{CO}$ concentration in the studied city (Jataí, Goiás, Brazil) was accepTable within the values recommended by CONAMA 03/90, not exceeding the averages, with significant differences between seasons and higher concentration in the spring, and lower in the autumn.

The city surveyed has an annual average temperature that oscillates around $22.2^{\circ} \mathrm{C}$, with maximum averages of $24.4^{\circ} \mathrm{C}$ and minimum averages of $18.2^{\circ} \mathrm{C}$. It presents a rainy period extending from October to April and a dry period corresponding to the months of June through August. The relative humidity of the air varies from 49 to $80 \%$ and, in the summer, it is highest in the hottest months of the year. In the spring, there is a transition from the rainy to the dry period, with intensification of vehicular traffic. In the fall, the green arborization makes the climate to become milder (BARROS; GUILHERME; CARVALHO, 2010).
Air pollution effects on human health are variable. It must be emphasized, however, that even when contaminants are within accepTable standards, other factors may contribute to the emergence of harmful effects such as temperature increases or oscillations, thermal inversions, wind regime, soil occupation with vertical constructions that prevent dispersion of pollutants, including CO (SETTE; RIBEIRO, 2011; JARDIM, 2011).

Although the averages recorded are within the standards suggested by CONAMA, which considers a concentration of up to $9 \mathrm{ppm}$ for a period of 8 hours as accepTable, as recommended by environmental agencies of the United States, California and the European Union, the recommendations of the Environmental Company Of the State of São Paulo (CETESB) says that values above $4.5 \mathrm{ppm}$ make air quality regular. For the present study, values during winter and autumn only were found to be within the range considered as good quality air, that is, 3.72 and $4.24 \mathrm{ppm}$, respectively (BRASIL, 1990; CETESB, 2007; IEMA, 2012).

The exponential growth of the population and the number of vehicles in the cities, as well as vertical constructions, causes the emission of polluting gases to increase and to keep in suspension for longer times, due to the difficulty to disperse. Thus, cities with highest population densities have a greater tendency to concentrate such effects, affecting the health of people in general, regardless the type of work (RADICCHI, 2012).

A study conducted with traffic police officers working in South India aimed at measuring $\mathrm{COHb}$ levels after exposure for three hours compared to office workers at a teaching hospital in 
the same region. Among participants, $76.5 \%$ of the traffic police officers had $\mathrm{COHb}>2.5 \%$, while no office clerk reached that level; furthermore, $41.2 \%$ of police officers had $\mathrm{COHb}$ levels $>4 \%(\mathrm{p}<0.05)$ (NAIR et. al., 2017).

As it is well established, tobacco use in any form alone causes increased $\mathrm{CO}$ exposure. When associated with environmental pollution, the level of $\mathrm{COHb}$ is even more increased among smokers, which exposes them to greater risk (DÓREA; BOTELHO, 2004).

In the present study, $\mathrm{COHb}$ levels among non-smokers were within the normal parameters in the three measurements, while these were elevated in the smokers. In the first measurement, they were 9 times higher; in the second, 4.39 times; and in the third, 4.74 times, with significant differences between overall means of smokers and non-smokers in the winter season. This fact shows that smoking causes $\mathrm{COHb}$ levels to remain altered, and workers are more likely to develop grievances related to environmental pollutant exposure, in addition to specific alterations in the respiratory system caused by substances present in tobacco (MAGA et. al., 2017).

The Brazilian Society of Pneumology and Tisiology recommends the value of $6 \mathrm{ppm}$ as an accepTable COex cutoff point. When applied to the conversion formula of the device used to measure and convert $\mathrm{COex}$ to $\mathrm{COHb}$, where this value is multiplied by 0.16 , a $\mathrm{COHb}$ value of $0.96 \%$ would be obtained. This is close to that recommended by the Ministry of Labor, which is $1 \%$ for non-smoking and not occupationally exposed people (TAMUSSINO \& CIA, 2013; REIS, 2008; SBPT, 2008). In the case of smokers, accepTable levels established in the literature are 4 to $5 \%$ for smokers who smoke between 20 and 40 cigarettes/day (NOLASCO, 2010).

A clinical trial conducted in Alabama with 673 volunteers aiming to identify the best cut-off point for COex upon cessation of smoking showed that the established levels were 3 to 4 ppm (0.48 0.64 of $\mathrm{COHb}$ ). It is also suggested that such limits need to be analyzed with caution, given the peculiarities of each population, as well as the levels of environmental pollution where they live (CROPSEY et. al., 2014).

A study carried out in Cuiabá, Mato Grosso, Brazil, with non-smokers who practiced physical exercise showed a COex mean of $2.69 \pm 0.88 \mathrm{ppm}$ and $\mathrm{COHb}$ of $0.43 \pm 0.14$, regardless sex and the practice of smoking $(\mathrm{p}>0.05)$ (SALICIO et. al., 2016). This finding agrees with that of the present study on the behavior of $\mathrm{COHb}$ levels, considering that non-smoking motorcycle taxi drivers presented the highest mean of $0.51 \pm 0.81 \%$.

In order to identify COex levels among smokers and non-smokers in places with different pollution levels, a study conducted in three Polish cities, Warsaw, Krakow and Kozienice showed that living in cities with less than 100,000 inhabitants was a protective factor for smokers and nonsmokers when compared to populations living in cities with 100,000 or more inhabitants. The average COex level, based on the cut-off point of $4 \mathrm{ppm}$, was significantly higher among smokers than among non-smokers $(\mathrm{p}<0.0001)$, and it was higher among non-smokers in large cities than non-smokers in small cities $(\mathrm{p}<0.0001)$. The mean level of exhaled $\mathrm{CO}$ was also found to be higher in active smokers in big cities than in small cities, but without statistical significance $(\mathrm{p}=0.14)$ (MAGA et. al., 2017).

These data allow us to infer that in the city studied (Jataí, Goiás, Brazil), a municipality with less than 100 thousand inhabitants and environmental CO levels within the recommended parameters, non-smokers had $\mathrm{COHb}$ values within the recommended, whereas smoking participants, the work represented a factor that increases $\mathrm{COHb}$ levels in this category.

A study carried out with 100 university students from the health area in Várzea Grande and the University of Cuiabá - MT showed that the average $\mathrm{COHb}$ found among smokers was $4.6 \pm$ 2.4\%, (95\% CI: 2.95 - 6.15), among former smokers was $2.3 \pm 1.1 \%$, (95\% CI: 1.41-3.18), among passive smokers, $2.3 \pm 1.2 \%$ (95\% CI: $1.65-2.94)$ and among non-smokers, $1.3 \pm 1.2 \%$, (95\% CI: 1.05-1.65) (BARROS et. al., 2012). The results of the present study are divergent in relation to the cited study, both for smokers and non-smokers. Increased $\mathrm{COHb}$ levels, despite pre-established patterns, present different values when measured at different locations, as influenced by the production and dispersion of $\mathrm{CO}$ levels.

As for the association between $\mathrm{COHb}$ levels and environmental $\mathrm{CO}$ values in the four seasons of the year, a significant correlation was observed only among non-smokers. The lack of significance among smokers may be due to the small number of participants, lack of control of the amount of cigarettes smoked per day, as well as the route travelled by the motorcycle taxi drivers. As the environmental quality is close to the recommended parameters, it can be assumed that levels that are already increased among motorcycle taxi drivers may have masked the interference of environmental $\mathrm{CO}$ in the formation of a greater amount of $\mathrm{COHb}, \mathrm{a}$ factor that tends to be overcome when it comes to 
larger cities, with higher levels of pollution (MAGA et al., 2017).

A study conducted in the city of Uberlândia, Minas Gerais, Brazil, with 111 participants verified the association between work-related accidents and $\mathrm{COHb}$ levels among motorcycle taxi drivers showed that those who had suffered accidents presented significantly higher average $\mathrm{COHb}(3.51 \% \pm 2.93)$ $(\mathrm{p}=0.020)$ (SILVA; ROBAZZI; TERRA, 2013). This allows us to infer that environmental exposure to carbon monoxide, along with increased $\mathrm{COHb}$ levels, add to the various factors contributing for the occurrence of traffic accidents, placing traffic workers at constant risk.

\section{Limitations}

The limitations of the present study are the small number of smokers, the lack of control of the amount of cigarettes smoked per day, and the absence of fixed stations to monitor pollutants.

The absence of measures of $\mathrm{COHb}$ levels in the spring season, which was not performed due to logistic difficulties, also represents a limitation.

\section{Authors' contributions}

SILVA, L. A. et al.

LAS participated in the conception of the study, design, data collection, analysis, interpretation and writing. MLCCR e RCMBD participated in the analysis, interpretation and critical review. HFA participated in data analysis, environmental assessment, critical review. LGM, SES, GSM participated in data collection, analysis and critical review. MFR participated in the critical review, writing. CCP conception of the study, design, analysis, interpretation and writing. All authors approved the final version of the article

\section{CONCLUSIONS}

$\mathrm{COHb}$ levels were higher among smokers, with statistical significance between the seasons of winter and fall, whereas the levels found among non-smokers were normal.

Environmental pollution by $\mathrm{CO}$ showed variation throughout the four seasons of the year and only among non-smoking motorcycle taxi drivers. There was a significant association with $\mathrm{COHb}$ levels, although still within normality parameters established by national and international environmental agencies.

RESUMO: Os estudos relacionados à poluição ambiental, níveis de monóxido de carbono e o tabagismo, necessitam de aprofundamento, com destaque para os trabalhadores do trânsito. Para tanto, verificar associação entre níveis de monóxido de carbono ambiental e carboxihemoglobina em mototaxistas tabagistas e não tabagistas. Estudo epidemiológico, longitudinal, realizado com 95 mototaxistas com mensuração do monóxido de carbono ambiental, carboxihemoglobina no ar exalado em três momentos com intervalo de seis meses, entre junho de 2014 e março de 2015, assim como as características sociodemográficas e ocupacionais desses trabalhadores. As estações do ano apresentaram diferentes médias de monóxido de carbono $(\mathrm{p}<0,05)$, com níveis maiores na primavera e menores no outono, enquanto os níveis de carboxihemoglobina entre tabagistas e não tabagistas apresentaram-se elevados no inverno, intermediário na primavera e baixos no outono. Observou-se diferença estatística entre subgrupos, no outono e na primavera para os não tabagitas $(\mathrm{p}=0,024)$ e entre o inverno e outono para os tabagistas $(\mathrm{p}=0,042)$. Houve correlação positiva entre os níveis de monóxido de carbono e carboxihemoglobina para não fumantes $\left(\mathrm{r}_{\mathrm{s}}=0,9983 ; \mathrm{p}<0,01\right)$. A poluição ambiental representou diferentes níveis nas quatro estações do ano e associação significativa com os níveis de carboxihemoglobina. Os níveis de carboxihemoglobina mostraram-se mais elevados nos tabagistas, com significância estatística entre a estação inverno e a do outono, enquanto os não tabagistas apresentaram níveis normais, o que reforça a participação direta do tabaco nos níveis de carboxihemoglobina.

PALAVRAS CHAVE: Poluição Ambiental. Hábito de fumar. Saúde do Trabalhador. Carboxihemoglobina.

\section{REFERENCES}

ACGIH- American Conference of Governmental Industrial Hygienists. Threshold limit values for chemical substances and physical agents and biological exposure indices. 1998-1999. Cincinnati, OH: ACGIH; 1999.

BRASIL. Conselho Nacional do Meio Ambiente (CONAMA). Resolução CONAMA n ${ }^{0} 03$ de 28 de janeiro de 1990. [Internet] 1990 [acesso 2017 mar 20]. Available at:

http://www.mp.go.gov.br/nat_sucroalcooleiro/Documentos/legislacao/especifica/03.pdf. 
BARROS, M. S.; SCHUCK, C. P.; MANA, V. M.; SALICIO, M. A.; SHIMOYA-BITTENCOURT, W. Avaliação da concentração de monóxido de carbono em estudantes universitários da área da saúde. Health Sci Inst., São Paulo, v. 30, n. 4, p. 399-405, 2012.

BARROS, E. F. S.; GUILHERME, F. A. G.; CARVALHO, R. S. Arborização urbana em quadras de diferentes padrões construtivos na cidade de Jataí. Revista Árvore, Viçosa-MG, v. 34, n. 2, p. 287-295, 2010.

Availableat: https://dx.doi.org/10.1590/S0100-67622010000200011

BLEEKER, M. L. Carbon Monoxide Intoxication. Handb. Clin. Neurol., Bethesda-USA, v. 131, p. 191-203, 2015. https://doi.org/10.1016/B978-0-444-62627-1.00024-X

CANÇADO, J. E. D.; BRAGA, A.; PEREIRA, L. A. A.; ARBEX, M. A.; SALDIVA, P. H. N.; SANTOS, U. P.. Repercussões clínicas da exposição à poluição atmosférica. J BrasPneumol.,São Paulo, v. 32, Suppl. 2, p. S5-S11, 2006. https://doi.org/10.1590/S1806-37132006000800003

CETESB - Companhia de Tecnologia e Saneamento Ambiental. Relatório de qualidade do ar no Estado de São Paulo 2007. São Paulo: CETESB; 2008.

CROPSEY, K. L.; TRENT, L. R.; CLARK, C. B.; STEVENS, E. N.; LAHTI, A. C.; HENDRICKS, P. S. How low should you go? Determining the optimal cutoff for exhaled carbono monoxide to confirm smoking abstinence when using cotinine as reference. NicotineTob Res.,Oxford-USA, v. 16, n. 10, p. 1348-1355, 2014.DOI 10.1093/ntr/ntu085

DÓREA, A. J. P.; BOTELHO,C. Fatores dificultadores da cessação do tabagismo: diretrizes para cessação do tabagismo. J BrasPneumol.,São Paulo, v. 30, Supl. 2, p. 41-46, 2004.

DRUMM, F. C.; GERHARDT, A. E.; FERNANDES, G. D.; CHAGAS, P.; SUCOLOTTI, M. S.; KEMERICH, P. D. C. Poluição atmosférica proveniente da queima de combustíveis derivados do petróleo em veículos automotores. REGET, Santa Maria, v. 18, n. 1, p. 66-78, 2014. https://doi.org/10.5902/2236117010537

IEMA - Instituto de energia e meio ambiente. Padrões de qualidade do ar: experiência comparada Brasil, EUA e União Européia. 2012 [acesso 2017 mar 29]. Availableat: http://www.energiaeambiente.org.br/wpcontent/uploads/2015/09/padroes-final01.pdf.

JARDIM, C. H. Relações entre temperatura, umidade relativa do ar e pressão atmosférica em área urbana: comparação horária entre dois bairros no município de São Paulo-SP. Geografias,Belo Horizonte, v. 7, n. 1, p. 128-142, 2011.

JATAÍ (município). Secretaria Municipal de Trânsito. SMT divulga frota de veículos em Jataí: demonstrativo do crescimento no número de veículos licenciados em Jataí período: Janeiro de 2007 a Abril de 2012. [Internet]. 2012. [Accessed March 20, 2017]. Available at: http://jatai.go.gov.br/index.php?option=com_content\&view=article\&id=3622\%3Asmt-divulga-frota-deveiculos-em-jatai $\&$ catid $=114 \% 3$ Atransito $\&$ Itemid $=300$

MAGA, M.; JANIK, M. K.; WACHSMANN, A.; CHRZĄSTEK-JANIK, O.; KOZIEJ, M.; BAJKOWSKI, M.; et al. Influence of air pollution on exhaled carbon monoxide levels in smokers and non-smokers. A prospective cross-sectional study. Environ Res., Amsterdam, v. 152, p. 496-502, 2017.

https://doi.org/10.1016/j.envres.2016.09.004

MENDES, P. C.; FERREIRA, D. A.; ROLDÃO, A. F.; SILVA, N. R.. Poluição atmosférica e saúde humana na cidade de Uberlândia-MG. In: $1^{\circ}$ Simpósio Internacional Saúde Ambiental e a Construção de Cidades

Sustentáveis, 2010, Uberlândia-MG. Anais..., v. 1, p. 639-48, 2010. 
NAIR, A. J.; NANDINI, M.; ADAPPA, S.; MAHABALA, C. Carbon monoxide exposure among police officers working in a traffic dense region of Southern India. Toxicology and Industrial Health, USA, v. 33, $\mathrm{n}$. 1, p. 46-52, 2017. https://doi.org/10.1177/0748233716654071

NOLASCO, D. Procedimento Operacional Padrão: carboxihemoglobina/ metahemoglobina. Belo Horizonte: Instituto Hermes Pardini; 2010.

OLIVEIRA, L. D. Os "Limites do Crescimento" 40 anos depois: das "Professias do Apocalipse Ambiental" ao "Futuro Comum Ecologicamente Sustentável". Revista Continentes (UFRRJ), Rio de Janeiro, ano 1, n. 1, 2012.

RADICCHI, A. L. A. A poluição na bacia aérea da região metropolitana de Belo Horizonte e sua repercussão na saúde da população. Revbrasestud popul., São Paulo, v. 29, n. 1, p. 195-198, 2012. https://doi.org/10.1590/S0102-30982012000100013

REIS, R. S. Segurança e medicina do trabalho: normas regulamentadoras. São Caetano do Sul: Yendis; 2008.

SALDIVA, P. (org.). Meio ambiente e saúde: o desafio das metrópoles. São Paulo: Ex-Libris Comunicação Integrada; 2010.

SALICIO, M. A.; MANA, V. A. M.; FETT, W. C. R.; GOMES, L. T.; BOTELHO,C. Variáveis ambientais e níveis de monóxido de carbono exalado e carboxihemoglobina em idosos praticantes de exercício. Ciênc saúde coletiva, Rio de Janeiro, v. 21, n. 4, p. 1023-1032, 2016. https://doi.org/10.1590/1413-81232015214.14502015

SBPT - Sociedade Brasileira de Pneumologia e Tisiologia. Diretrizes daSBPT: diretrizes para cessação do tabagismo - 2008. J BrasPneumol., São Paulo, v. 34, n. 10, p. 845-80, 2008.

SENECHAL, H.; VISEZ, N.; CHARPIN, D.; SHAHALI, Y.; PELTRE, G.; BIOLLEY, J. P.; et al. A review of the effects of major atmospheric pollutants on pollen grains, pollen content, and allergenicity. Sci World J., Londres, ID 940243, 29 p., 2015. https://doi.org/10.1155/2015/940243

SETTE, M. S.; RIBEIRO, H. Interações entre o clima, o tempo e a saúde humana. Revista de Saúde, Meio Ambiente e Sustentabilidade,São Paulo, v. 6, n. 2 p. 37-51, 2011.

SILVA, L. A.; ROBAZZI, M. L. C. C.; TERRA, F. S. Associação entre acidentes de trabalho e os níveis de carboxihemoglobina em trabalhadores mototaxistas. Rev Latino-AmEnfermagem, Ribeirão Preto, v. 21, n. 5, p. 1119-1126, 2013. https://doi.org/10.1590/S0104-11692013000500015

SIQUEIRA, M. E. P. B.; MARTINS, I.; COSTA, A. C.; ANDRADE, E. L.; ESTEVES, M. T. C.; LIMA, S. A.. Valores de referência para Carboxihemoglobina. RevSaude Publica,São Paulo, v. 31, n. 6, p. 618-263, 1997. https://doi.org/10.1590/S0034-89101997000700010

TAMUSSINO \& CIA Ltda. Micro CO: Medidor de Monóxido de Carbono Expirado. [Internet] 2013 [acesso 2017 mar 20]. Availableat: http://www.tamussino.com.br/pt/produto-det.php?rp=808. 